\title{
2008 Avro Krizine Post-Keynesyen Bir Bakış
}

\author{
Ferda DÖNMEZ ATBAŞI \\ donmez@politics.ankara.edu.tr
}

\section{A Post-Keynesian View on 2008 Euro Crisis}

\begin{abstract}
This article evaluates the dynamics behind the contagion of 2007 US Subprime crisis to the European Monetary Union from a Post-Keynesian view. In doing that, it focuses on the peculiarities of the union regarding its structural difference from the USA, the fragility of the European financial architecture and the trade pattern. Rather than traditional orthodox arguments of inefficient governance, public extravagance or rigidities in the labor market, it elaborates on the dual character and hegemonic production relations of core and periphery within the union. Emergence of financial privatized Keynesianism, neomercantilism and internal devaluation are its basic focal points.
\end{abstract}

Keywords

JEL Classification Codes : $\quad$ E12, F16, G01, G18.

: $\quad$ Euro Crisis, Financialization, Neomercantilism, Privatized Keynesianism, Internal Devaluation.

\section{Özet}

Bu makale 2008'de ABD'de emlak piyasasında başlayan ve daha sonra tüm sektörlere ve dünyaya yayılan krizin, Avrupa Parasal Birliği’de sıçramasının arkasındaki dinamikleri Post-Keynesyen bir açıdan tartışmaktadır. Bunun için bir yandan, ABD ve Avrupa Parasal birliğinin yapısal farklılıklarını ele alırken, diğer yandan birliğin ikili yapısı ve merkez ile çevre arasındaki hegemonik üretim ilişkilerine dikkat çekmektedir. Finansal özelleştirilmiş Keynesçiliğin ortaya çıkışı, neomerkantilizm ve dahili devalüasyon makalenin özellikle dikkat çektiği kavramlardır.

\section{Anahtar Sözcükler}

Avro Krizi, Finansallaşma, Neomerkantilizm, Özelleştirilmiş Keynesçilik, Dahili Devalüasyon. 
Ferda DÖNMEZ ATBAŞI 


\section{Giriş}

Bundan üç yıl önce The Economist dergisinin 2011 Kasım tarihli makalelerinden birinde ${ }^{1}$ Avro bölgesi liderlerinin bir araya gelerek, kapsamlı bir avro kurtarma görüşme dizisi başlattıklarından söz ediliyordu. Buna göre, Fransa Avrupa Merkez Bankası (AMB) kanalıyla kurtarma fonlarının oluşturulmasını isterken, Almanya bunu kesin olarak reddediyordu. Sözü edilen kurtarma paketinin birbiriyle ilgili üç önemli ayağı vardı. İlk olarak Yunanistan borçlarının yarısının gönüllü özel kreditörler aracılığıyla silinmesi ve bu sayede borcun yarısının daha güvenli, ödenebilir borç haline getirilmesi öngörülüyordu. Bununla birlikte Yunanistan'dan alacağı olan Avrupa bankalarının yeniden-değerleme yaparak bu ödenmeyen yarıdan kaynaklanacak kaybı gidermeleri bekleniyordu. Nihayet Avrupa kurtarma paketinin 1 trilyon avroya yükseltilerek, kriz nedeniyle iflas durumunda olmayan ama kısa vadede ödeme sıkıntısı yaşayan ekonomilere -İtalya, İspanya, İrlandasıçramasının önlenmesi planlanıyordu. Makale finans troykasının - IMF, AMB ve Avrupa Komisyonu- artık Yunanistan'ın borçlarını ödeyemeyeceğini kabul ettiğini ve bunun da iyi bir gelişme olduğunu belirtiyordu.

Hemen her yerde sözü edilen ve güney Avrupa ülkelerinin bazılarının kurtarılmasını gerektirecek bu iktisadi darboğaz, 2008'de ABD'de yaşanan emlak krizi ve sonrasında gelişen derin durgunluktan kaynaklanmış görünüyordu. Fakat Avrupa Parasal Birliği'nin yapısal sorunlarının varlığı da aynı dönemde çokça dile getirilmeye başlanmıştı. Acaba büyük umutlarla kurulan iktisadi ve daha sonra da parasal birlik olmuş Avrupa bloğunu, dünyanın başka bir yerinde başlayan bir çalkantıdan bu denli ciddi etkilenir hale getiren mekanizmalar nelerdi? ABD'de böyle bir kriz yaşanmamış olsaydı, Avrupa kendi içinde uyumla çalışan ve birliğin görece geri kalmış ekonomilerinin gelişkin ekonomilere yakınsadığı bir iktisadi blok olabilir miydi? Avrupa para birimi Avronun birliğin farklı gelişmişlik düzeyindeki ekonomileri için yarattığı sonuçlar nelerdi?

$\mathrm{Bu}$ makalenin amacı bu sorulara yanıt bulmak ve bunu yaparken de, geleneksel kötü yönetim, kamu müsrifliği, emek piyasalarındaki katılıklar gibi açıklamaların dışına çıkarak, özellikle Post-Keynesyen yaklaşımların bir derlemesini yapmaktır.

\section{2. Özelleştirilimiş Finansal Keynesçilik}

2008 ABD'sinde başlayan ve daha sonra "büyük durgunluk" olarak adlandırılan süreç, kapitalist birikim tarihinin en derin ve yaygın etkili krizlerinden biri olarak gösteriliyor. Büyük durgunluğun başladığı 2008 yılından bu yana, krizin ABD'de nasıl ortaya çıktığı ve daralan ABD ekonomisinin, ABD'ye sürekli ticaret fazlası veren dünyanın geri kalanına teknik olarak nasıl sirayet ettiği çokça yazılıp çizildi. Bu nedenle meselenin o tarafı bu makalede ele alınmayacaktır. Bizim özellikle bu bölümde yapacağımız şey,

I The Euro Deal, No Big Bazooka. 
kapitalist birikim sürecinin yeni bir fazı olarak ‘özelleştirilmiş Keynesçilik’ kavramıyla ifade edilen döneme yoğunlaşarak, ABD ile Avrupa arasındaki iktisadi ilişkileri nasıl etkilediğini tartışmaktır.

II. Dünya Savaşı ve takip eden dönemde, efektif talep sorunları Kalecki'nin 'yerel ihracat' dediği mekanizmayla çözülmüştü. Bir başka deyişle, dönemin temel özelliği özel sektörü besleyen ve para politikası ile fonlanan kamu açıklarının varlığı olmuştur (Bellofiore, 2013, 499). Bu işleyiş bir süre kalıcıymış görüntüsü veren bir tam istihdam durumu yaratmış olsa da, göreli ücretlerin aşağı doğru baskılanmasına direnecek bir işçi hareketini de beraberinde doğurmuştur. Böylece, Fordist dönemi sonlandıran tek gerilim olmasa da, emek-sermaye ve ortaya çıan ürünün nasıl bölüşüleceği gerilimi sosyal bir kriz doğurmuştur (Bellofiore, 2013: 499).

Bu nedenle, 1970'lerin başında iyice kendini hissettiren sosyal krize cevaben ortaya çıkan Reaganizm-Thatcherizmin para arzını baskılayan, reel ve nominal faiz hadlerini ciddi oranda arttıran ve böylece özel yatırımları daraltan, parasalcı bir ekol oluşu tarihin bir cilvesi değildir. Sendikalar üzerindeki baskı ve yıldırmaların yoğunlaşması, ücretler ve sosyal harcamalardaki kısıntılar yani kamusal harcamaların en aza indirilme hamlelerinin 1929'dakine benzer bir büyük yıkım yaratması ihtimal dâhilindeydi. Bu nedenle, kamusal harcamalardaki daralmayı dengeleyecek ve fakat bizzat piyasaya dayanacak ayarlama mekanizmalarına ihtiyaç vardı. İşte de tam da bu ihtiyaca cevap olarak, dönemin ABD hükümeti 'ikiz açık' politikasını uygulamaya başladı (Bellofiore, 2013: 499). Bütçe açığı yerli talebi karşılarken, ticaret açığı da Avrupa ve Asya'nın ihracata dayalı büyüme stratejilerinin devamını garanti ediyordu. Dolayısıyla, ABD'nin ikiz açık vermesi hem kendi iç pazarını ve hem de dünya pazarını memnun eden bir ayarlama mekanizmasıydı.

İkinci mekanizma ise literatürde 'özelleştirilmiş Keynesçilik' kavramı ile açıklandı (Crouch, 2009: 388). Keynesyen dönemin sorunsuz işlediği II. Dünya Savaşı sonrası dönemde bile, kamunun ekonomiden elini olabildiğince çektiği 'gerçek piyasa ekonomisi'ne dönüşü savunan karşı görüşler tamamen ortadan kalkmamıştı. Fordist üretim rejimi ile eşleşmiş Keynesyen bölüşüm rejimi endüstriyel üretimde istihdam olmuş geniş işçi yığınları ile sermayedar kesimin çıkarlarını ortaklaştırmış görünmekteydi. İşyerinde iş bölümü had safhaya çıkıp, üretim miktarı masif bir şekilde artarken işçinin işe ve kendine yabancılaşması da artıyordu. Bunun telafi yöntemi ise, ücret akışlarının devam edeceği beklentisinin sağlanması ve gerçekleşmesiydi. Yığınlar hem pastadan önceki dönemlere kıyasla daha yüksek bir pay alıyor ve sisteme içeriliyordu ve hem de yarattıkları etkin talep kapitalist yığınsal üretimin motoruna yakıt sağlıyordu. Ancak 1970'lerde baş gösteren enflasyonist krizler, varlığını hep koruyan piyasacı görüşlere iktisat politikası gündeminde yeniden baskın görüş olmak için ihtiyaç duydukları iktisadi ortamı sağladı.

Takip eden on yıl içinde, işsizlik anlamında sonuçları ne olursa olsun sıfıra yakın enflasyon politikasının mutlak öncelik sahibi olduğu, kamu harcamalarının sonuna kadar kısıldığı, darboğazlardan geçen firma ya da sektörlere devlet yardımının ortadan kalktı̆̆ı, 
rekabetin temel olduğu, mal, hizmet ve finansal piyasaların tamamen serbestleştiği kapitalist model ana akım haline geldi (Crouch, 2009: 388). Bundan sonra küreselleşme olarak anılan ve dünya piyasalarının birbirlerine kısıtsız olarak eklemlenebildiği bu dönem, bir sınıf olarak finansal kapitalistler diyebileceğimiz grubun çıkarlarına hizmet eden ve Keynesyen dönemin işçi sınıfı kazanımlarını inişe geçiren bir dönem olmuştur. Öyle ise savaş sonrası dönemde çıkarları çok acil ve önemli olan endüstriyel işçi yığınlarının kaderi ne olmuştur? Başka bir deyişle, sistem kendi devamını garanti altına alabilmek için, geniş işçi yığınları hareketlerini ve talep baskısını nereye ya da neye kanalize etmiş̧tir (Crouch, 2009: 389)?

Öncelikle belirtmek gerekir ki, dünyanın hemen her yerinde endüstriyel işçi yığınları toplam çalışanların çoğunluğu değildir ve fakat yaygın olarak en örgütlü ve küreselleşme dönemine kadar da hızla genişleyen grubudur. Ancak, yeni dünya düzeninde ekonomilerin en hızlı genişleyen sektörü artık endüstriyel sektörler değil, özel hizmetler sektörüdür (Crouch, 2009: 389). Sanayi proletaryasının haklar, çalışma koşulları ve nüfus olarak erozyona uğradığı neoliberal küresel düzenin yeni gözdesi hizmetler sektörüdür. Diğer yandan, hizmetler sektörü geleneksel sektörlere nazaran, çalışanlarının örgütlü olmadığı, ya da emek hareketlerinin çok zayıf olduğu sektörlerdir. 1980'li yılların daralan kamu yatırım ve istihdamları ile sanayi ve tarım sektörlerinin kan kaybetmesi de, yarattığ işsizler ordusu ile bu gidişatı pekiştiren gelişmeler olmuştur. Devletlerin özerklikleri uluslararası piyasada gittikçe azalırken, bu alanın yeni hegemonları çok uluslu şirketler olmuştur. Gelinen bu noktada, devletlerin uluslararası finansal hareketlerin piyasalarda yaratabileceği çalkantılardan duyduğu endişe, olası emek hareketlerinin yaratabileceği istikrarsılılklardan duyduğu endişenin çok ötesine geçmiştir. Bir yandan uluslararası sermaye hareketleri tamamen serbestleşirken, diğer yandan orta sınıfların ve iş̧i hanehalklarının tasarrufları özel yatırım kuruluşları ya da bankalar aracılığıyla serbestleştirilmiş finans piyasalarına yönlendirilmiştir. Bunun sonucu olarak da finans piyasaları 1sınmış, ortaya baş edilmesi güç bir varlık fiyat enflasyonu çıkmıştır (Bellofiore, 2013: 499).

Finansal yapılanma, paranın toplandığı özel fonlardan finansal piyasalara akışını hızlandırdıkça, reel üretim yapan firmaların hisse satış maliyetlerini düşürüyordu. Ancak bu hisselerin geri ödemeleri artık büyük ölçüde spekülatif etkinliklere bağlıydı. Bu süreç, reel üretim yapan firmaların aşırı-sermayeleşmesine neden oluyordu (Toporowski, 2010'dan aktaran Bellofiore, 2013: 500). Finansal piyasalardaki bu anormal genişlemeyle toplanan fonlar büyük oranda kısa vadeli varlıklara yatırıldığı için, kendi kendini dengeye getirici bir mekanizma olmaksızın, varlık fiyatları üzerinde artış yönünde bir baskı oluşturuyordu. Bankacılık sektörünün temel faaliyeti, üretken projesi olan müşserileri bulup fonlamak olmaktan çıkıp, menkul kıymetleştirme ve hane halklarına kredi açmak oluyordu. Burada dikkat çekilmesi gereken nokta, toplam borçluluğun reel üretimdeki genişleme nedeniyle değil, finansal faaliyetlerdeki ve hanehalklarının borçluluğundaki tırmanış nedeniyle artmış olmasidır. 


\section{Grafik 2.1}

Hane Halkı Borçluluk Oranı, Harcanabilir Gelirin \%'si Olarak

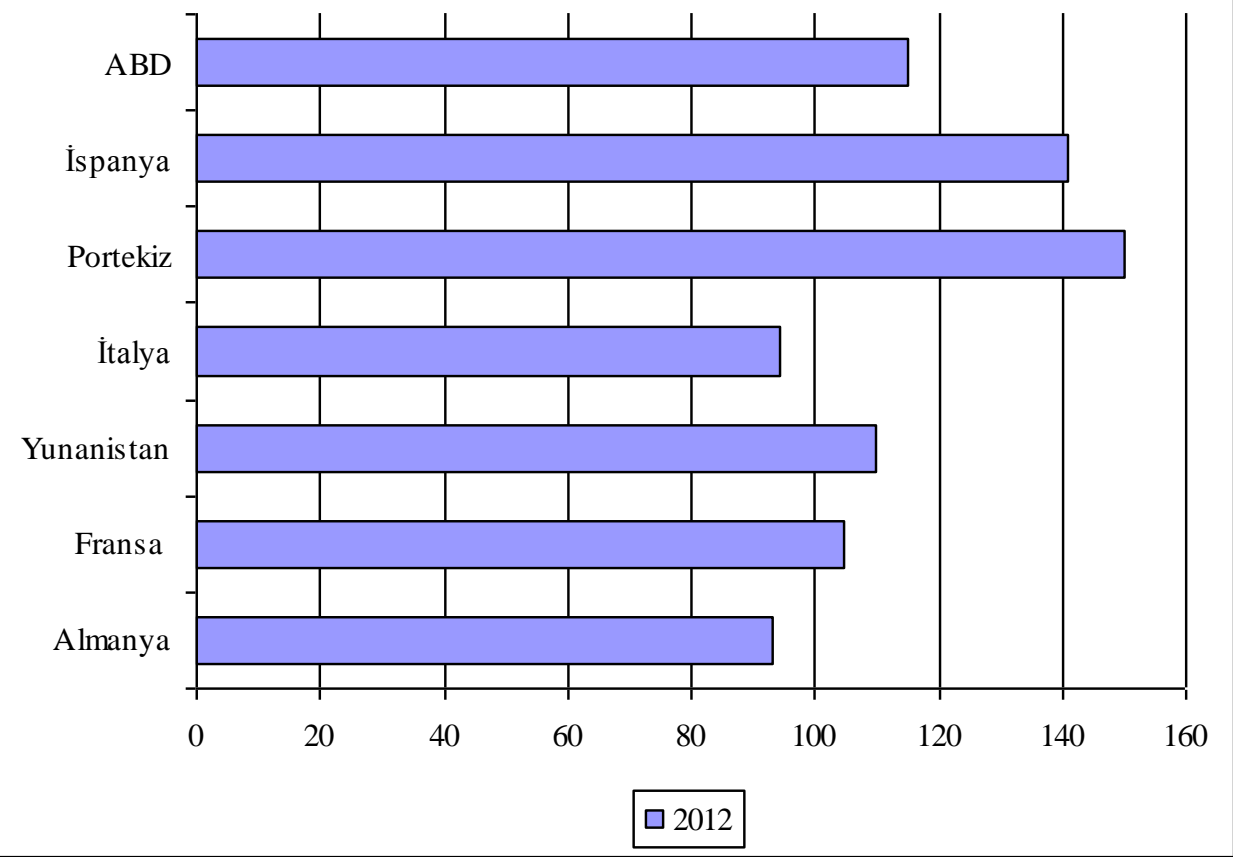

Kaynak: 〈data.oecd.org〉, 23.02.2014.

Bir örnek teşkil etmesi bakımında Grafik 2.1'de 2012 yılı için harcanabilir gelirlerinin yüzdesi olarak hane halkı borçluluk oranları görülüyor. Özellikle Avrupa'nın ülkelerinde gelirin tamamının üstünde bir borçluluk oranı gözlenmekte ve özellikle Portekiz ile İspanya bu anlamda en kırılgan ekonomiler olarak öne çıkmaktadır.

Borsalardaki ve emlak piyasalarındaki genişleme, krediye dayalı tüketim harcamalarını besliyordu çünkü bu yeni düzende harcamalar gelirden bağımsız bir hale gelmişti. Ücretleri kısıp, işçi mücadelesini zayıflatıp, tüketim alışkanlıklarının borçluluk üzerinden devamını sağlamak, Keynesyen dönemde sıkışmış kâr hadlerinin eski seviyesini yakalaması ve hatta geçmesi için tasarlanmış bir örüntüydü. Burada hem toplumsal bölüşüm ilişkileri bir kez daha sermaye kesimi lehine şekillendiriliyor ve hem de borçluluk ilişkisi yeniden düzenleniyordu. Çünkü artık, kredi paranın ekonomiye giriş noktası yatırım 
projesini fonlayan sanayi firmasının ödenecekler kalemi değil, bizzat hane halklarının cepleriydi.

$\mathrm{Bu}$ yeni kapitalist dönemde merkez bankalarının rolü de, menkul kıymet fiyat enflasyonunu desteklemek için ilk borç verme mercii olarak değişmişsti (De Cecco, 1998'den aktaran Bellofiore, 2013: 501). Greenspan aracılığıyla para arzı kısıtlaması ortadan kalkmıştı ve merkez bankasının belirlediği herhangi bir faiz oranında sınırsız likidite sağlanıyordu. Böylelikle, para arzı ana akım iktisatçılar arasında bile içse ${ }^{2}$ olarak tanındı. Sonuç olarak, efektif talep doğrudan, borçla gerçekleştirilen harcamalar yoluyla siyaseten yönetiliyordu. Şu ana kadar ana hatlarıyla anlatmaya çalıştığımız bu faza 'özelleştirilmiş finansal Keynesçilik' deniyordu.

ABD’nin başı çektiği bu yeni kapitalist birikim dönemi giderek daha fazla finansallaşmaya, emek piyasalarında kuralsızlaşmaya dayanıyordu. Bu gidişat gelir ve servet eşitsizliğini arttırırken borca dayalı tüketimi de gittikçe yükseltiyordu. Diğer yandan, tam olarak bu borca dayalı tüketim genişlemesi, büyüme stratejileri sürekli cari fazla vermek olan Almanya, Japonya gibi neomerkantilist ekonomileri ayakta tutuyordu (Bellofiore, 2013: 501). Ancak 2000'lerin hemen başında patlayan dot-com balonu ya da 2007'de ABD'de patlak veren emlak piyasası balonu gibi bütün toplumsal ve iktisadi hayatta derin etkiler yaratan kriz durumları, tarif edilen bu fazın devam ettirilebilirliğini tartışmaya açmıştır.

\section{Avrupa'da Neomerkantilizm ve Avronun Kısa Tarihçesi}

En sade tanımla, neomerkantilizm büyümenin kaynağını ticaret fazlası vermek olarak gören yaklaşımdır.

Bilindiği üzere, neomerkantilist model ilkin 1932’de İngiliz İşçi Partisi seçimleri kaybedip muhafazakârlar iktidara geldiğinde emarelerini göstermeye başlamıştır. 30'lu y1llar o zamana kadar serbest piyasanın erdemlerini öven İngiltere başta olmak üzere, kapitalist ekonomilerin korumacı mimariyi inşa ettiği yıllar olmuştur. $\mathrm{O}$ zaman kadar görülmemiş bir uygulama ile İngiltere'nin ithalatta \%10 gümrük vergisi artırımına gitmesi ve peşinden Tercihli İmparatorluk Sistemi ${ }^{3}$ 'nin uygulamaya koyması, ihracatları için pazar garantisi yaratıp, ithalatlarını da azaltmayı hedefleyen tipik neomerkantil politikalar olarak

2 Para arzının içselliği tartışmalarının detayı içi Moore (1988), Palley (1991) ve Arestis ve Sawyer (2006)'ya bakiniz.

3 Bu sistemde İngiltere ve 12 Dominyon arasinda bir tercihli ticaret alanı oluşturuluyordu. İngiltere'nin beklentisi dominyonlartn kendisine ilelebet glda ve hammadde, Ingilte'nin ise dominyonlara mamul mal ihracatı yapmasıydı. Bunu sağlayacak altyapıyı da anlaşmalarda inşa etmeyi başarmıışt. Daha sonra 1933 'te bu tercihli ticaret alanina İngiliz kolonileri de dâhil edildi (Kuruç, 2011: 106-107). 
öne çıkıyordu. Döviz Kurlarını Yönetme Hesabı''nın başarıyla işletilerek sterlinin korunması ve ilerleyen yıllarda özel kesime orta vadeli ihracat kredisi için devlet desteği verilmesi İngiltere'nin serbest piyasa yaklaşımından giderek uzaklaşarak kendini korumacı politikalarla inşa ettiğinin temel göstergeleri olmuştur. Dolayısıyla 1931'de altın standardını terk ettikten sonra kendisine sağlam bir yol arayan İngiltere, II. Dünya Savaşı öncesi dönemi bu tedbirleri alarak geçirmiştir (Kuruç, 2011: 104-108).

I. Dünya Savaşı'ndan yenik çıkan Almanya'nın iki savaş arası dönemde ekonomik sıkıntılarla boğuştuğunu tarih kitaplarından biliyoruz. Özellikle ABD’nin savaş tazminatlarının ödenmesindeki ısrarı ve bunu sağlayabilmek için önce Dawes Planı ve sonra da Young Planı'nı uygulamaya koyması ile ABD özel sektörü tarafindan Almanya'ya açılan krediler, Alman sermayesini çok tatmin etmişti. Ancak 1931 yılına gelindiğinde, Almanya'nın artık tazminat ödeyemeyecek durumda olduğu çok açıktı ve dış borçlanma zaten çok yüksek olduğu ve birinci savaş sonrasında yaşanan hiper enflasyonun geri gelmesinden korkulduğu için elde kalan tek yol olan kemer sıkma politikalarına yönelindi. Ücretlerde yüksek kısıntılar, vergi artışları ve işsizlik ödeneğinin budanması işsizliği büyük boyutlarda arttırırken, gittikçe yoksullaşan Alman halkının dayanacak gücünün kalmadığını dünyaya ilan ediyordu. ABD'nin büyük buhranla baş etmeye çalıştı̆̆ı bu yıllarda Almanya'nın İngiltere ve Fransa'ya (ve sonuç itibariyle onların da kendisine) ödeme yapamayacağına kanaat getiren ABD başkanı Hoover ödemelerin bir yıl ertelenmesini öngören moratoryumu açıklasa da Almanya için geç kalınmıştır. Krizin de etkisiyle banka sistemi çökmekte olan Almanya'da faiz oranları \%15'e yükseltilir, kısa vadeli borç ödemeleri durdurulur, tüm dövizler merkez bankasına toplanır ve ülke dışına para çıkışına katı engeller konulur. Adı konmamış bu Mark koruma tedbirleri aslında fiilen altın standardının terk edildiği anlamına gelmektedir (Kuruç, 2011: 120).

Almanya'yı 1940’larda bile sistematik cari fazla verip Avrupa-içi açıları fonlayan bir konuma getiren yolun başı bu politikalardan geçmekte iken, 1929'da Almanya'nın borçlarını takip için kurulan ve yoğun olarak kredi açan Uluslararası Ödemeler Bankası (Bank of International Settlements, BIS)'nın da bu sonuçta önemli bir payı olduğunu unutmamak gerekir. Kuruluşuna beş merkez bankasının (İngiliz, Fransız, Belçika, İtalya ve Alman) garanti verdiği BIS'in Almanya'ya yaptığı yatırımlar, ülkenin savaş sırasında bile faiz ödeyecek denli sağlam bir duruma gelmesinde çok kritik bir rol oynamıştır (Kuruç, 2011: 122).

Takip eden yirmi yıl içinde güçlü ihracat performansında Almanya'ya, Fransa ve İtalya da katılmıştır. Ancak doğaldır ki, bir bütün olarak Avrupa'nın ticaret fazlası vermesi imkânsızdır (ticaretlerinin bir bölümü kendi aralarındaki ticarettir). Başka bir ayarlama

4 ... "Ekonomiye dışarıdan para girişi halinde, bunun karşıllğ̆ olarak, bu hesaptan sterlin cinsinden Hazine kâğıdı çıkarılıyordu. Bunlarla döviz satın alınıyor, o da altına çevriliyordu. Sermaye çıkışı halinde.....tersi yapılıyordu: Altın ile döviz, onunla da sterlin cinsi kağıt satın alınıyor ve bu mekanizma ile sermaye giriş-çıksşı sterilize ediliyor, para politikası üzerinde doğacak etkilerden arındırllıyordu (Kuruç, 2011: 107). 
mekanizması olmadığı durumda açık veren ülkeler, ayarlama yapabilmek için ya bir daralma döneminden geçmek (ki bu fazla veren ülkelerde üretim ve istihdamı olumsuz etkiler) ya da ulusal parasını devalüe ederek yoluna devam etmek zorundadır.

Ancak ne Avrupa Para Sistemi (1979-1999), ne de mevcut Avrupa Parasal Birliği gibi sabit kur rejimlerinde devalüasyon bir seçenek olarak yer almaktadır. Aslında Avrupa Para Sistemi $\left(\mathrm{EMS}^{5}\right)$, cari hesap dengesi bakımından Avrupa'yı ikiye bölmüştür. Fazla tarafinda Almanya ve uyduları ${ }^{6}$, açık tarafında ise İtalya vardı. İtalya parasını devalüe edebildiği anda net ihracatlarını artıya geçirmesi mümkündü, ancak İspanya, Portekiz ve Yunanistan açık tarafının üretim kapasitesi anlamında da daha zayıf bileşenleri olarak ortaya çıkıyordu. Fransa'nın ise kendine has bir durumu vardı. Üretim kapasitesi ve rekabet gücü anlamında kendisini Almanya ile eşit gören Fransa'nın bu tutumu, cari hesabını giderek daha hızla bilançonun eksi tarafına itmiştir. Düştükleri açık pozisyonunda, Almanya'nın parasal istikrarından yararlanma fikri Fransız politika yapıcıları tek para birimi rejimine koşullanmıştır. (Bellofiore, 2013: 503).

Doğu ve Batı Almanya'nın birleşmesinin (1992-93) maliyeti sadece vergilerle karşılanamayıp, mali açık ve sermaye ithalatı ihtiyacı da doğunca, bu politikalara tamamen karşı bir pozisyon alan Alman Merkez Bankası kısa vadeli faizleri keskin bir biçimde arttırmıştır (1991-92). Takip eden dönemde Alman Markı hızla değer kazanmış ve sekiz yıl sürecek olan cari açık dönemine girilmiştir. Burada altını çizmek gerekir ki, Batı Almanya hala gayet önemli miktarlarda fazla veriyordu ancak bu fazlalar Doğu Almanya'nın devasa birikmiş açıklarını kapatmaya yetmiyordu. Bundesbank'ın enflasyon baskısını engellemek için uyguladığı yüksek faiz politikası iç talepteki ve ücretlerdeki artışı dengelemekte başarılı olamamış ve Almanya neomerkantilist pozisyonunu koruyamamış gibi görünebilir. Ancak, birleşmeyi takip eden yıllar, Alman ekonomisinin başta emek piyasası olmak üzere çok güçlü bir yeniden yapılanmaya gittiği yıllar olmuştur. Üretimi Doğu Avrupa başta olmak üzere diğer EU-15 ülkelerine taşımış ve maliyet yapılarını değiştirmiştir. Tek para birimi uygulamasına geçilmesiyle birlikte parasal birliğin diğer bileşenlerini sabit döviz kuru kapanına sıkıştırmış ve 2000'lerin ihracat şampiyonu Almanya'sı olmayı başarmıştır (Bellofiore, 2013: 504, Bellofiore, Garibaldo ve Halevi, 2010 ).

5 Avrupa Para Sistemi (EMS) Avrupa iktisadi politikalarının entegrasyonu için bir ön adım olarak hayata geçirilmiştir. Amacı Avrupa ülkelerinin enflasyon oranı farklllıklarını gidererek döviz kurlarını yakınsatmak ve böylece bölgede kur istikrar tesis ederek, ticaret hacmini arttırmak ve düzenlemekti. En azından Avrupa'da rezerv para olarak $A B D$ dolarının yerini alması için ECU (European Currency Unit) de bu evrede uygulmaya sokulmuştur. Daha detayl bilgi için Edison ve Fischer (1991)'e bakinız.

6 Hollanda, Belçika, İsviçre, Avusturya, Finlandiya ve İsveç (Bellofiore, 2013, 502). Bu ülkeler Avrupa'nın geri kalanina net ihracat yaparken, Almanya' ya açık veriyorlard. 


\section{Avrupa Ülkeleri için Ölü Doğum: Avro}

Avrupa Birliği'nin tek para rejimine geçişi daha işin başında kırılgan nitelikler taşıyordu. Üye ülkelerin üretkenlik farkları, süregiden endüstriyel yeniden yapılanma süreci, teknolojik seviye farkları ve altyapı farkları, birliği son derece heterojen bir yapı haline getiriyordu. Böyle bir yapının nominal bir ölçütle -avro ile- tek bir çatı altına alınması, aslında yapının zayıf parçaları ile güçlü parçaları arasındaki reel farkları daha da arttırmaktan başka bir işe yaramadı.

Krizler karşısında $\mathrm{ABD}$ ve Avrupa Birliğinin karşı karşıya kaldığı durumların farklılaşması yapısal farklılıklarından ileri geliyordu. Şöyle ki, ABD olası açık ya da ikiz açık durumlarında her zaman genişleme politikası izleyerek krizi atlatıyor bu yüzden devlet borcu krizi, borçları ve açıkları daha fazla olmasına rağmen Avrupa'nınki kadar ciddi olmuyordu. Avrupa'nın merkezi ise olası açık durumunda, açığın parasallaştırılması olasılığının enflasyon beklentisi yaratacağını düşündüğü için sıkı politikaya geçmeyi tercih ediyordu (Arestis ve Karakitsos, 2012).

Diğer yandan, $\mathrm{ABD}$ ve Avrupa her zaman farklı parasal birlik yapılarına sahip olmuşlardır. $\mathrm{ABD}$ bir 'optimum para birimi' bölgesidir. Yüksek emek ve sermaye hareketliliği vardır ve sermaye transferleri ile birlikte federal hükümetin garantisi altındadır. Avrupa ekonomik ve parasal birliği ise mali bir birlik üzerine inşa edilmiş değildir. Vergi toplayan ve harcama yetkisi olan ortak bir mali organı yoktur. Emek hareketi dil ve kültürel farklılıklarla belirli bir hacme mahkûm olurken, sermaye hareketi bürokratik yapıların tam olarak uyumlu olmaması nedeniyle beklenenden daha azdır. Başlangıçta parasal birliği ayakta tutmanın temel aracı sermaye transferleri olarak görülmüştür. Ancak, birlik tam istihdam ve büyüme amaçlarını öteleyen ve bu amaçlara ulaşmak için mali araç kullanmayı kısıtlayan bir yapı getirmiştir. Dolayısıyla parasal birlik kurulduktan sonra reel büyüklüklerde (büyüme, üretkenlik) ülkeler birbirinden uzaklaşıyordu ve Avrupa Birliği'nde yaşanan borç krizlerinin altında yatan temel neden bu olarak görülebilirdi. (Arestis ve Karakitsos, 2012). 


\section{Grafik 4.1}

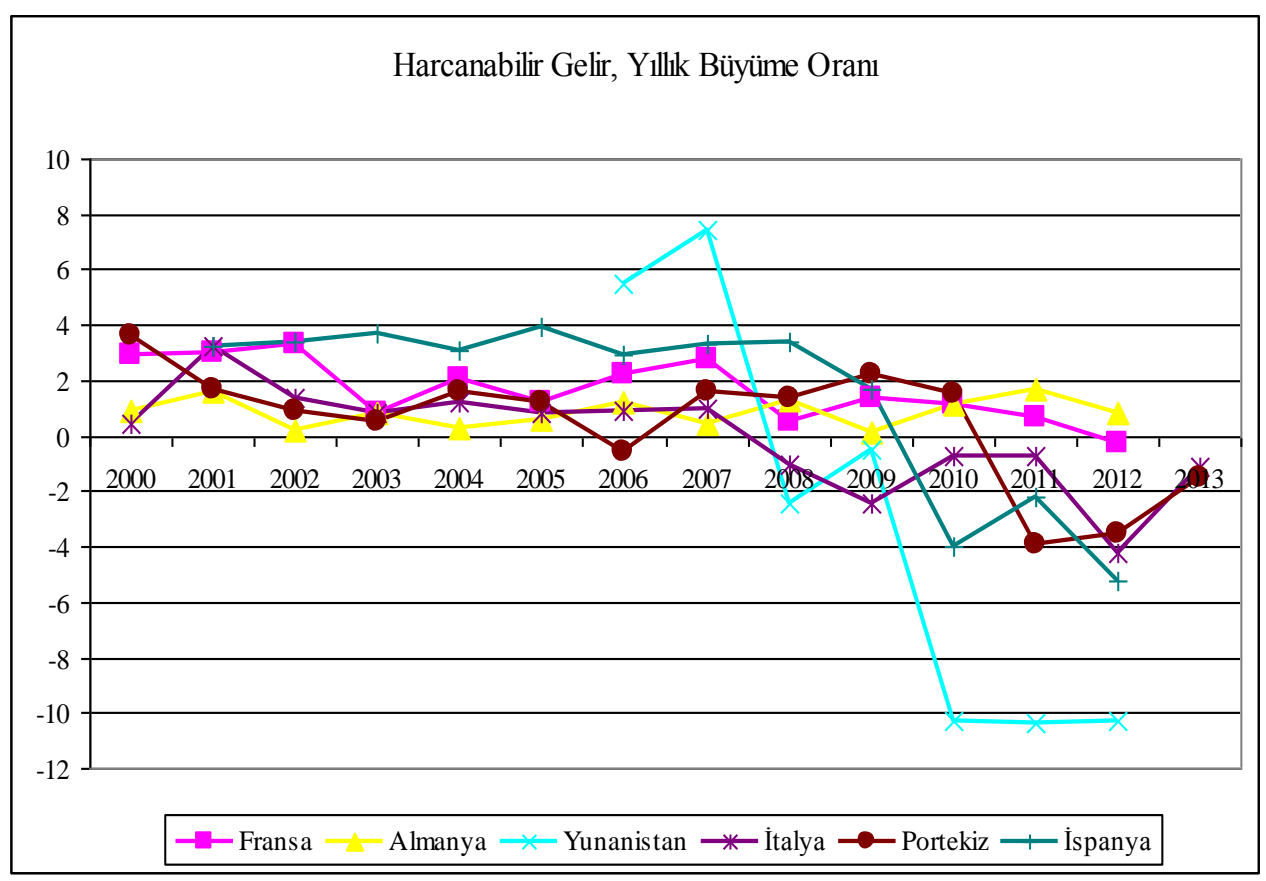

Kaynak: <data.oecd.org>, 23.02.2014.

Grafik 4.1'de Avrupa'nın merkez ve sini temsilen seçilmiş ülkeler için harcanabilir gelirin yıllık büyüme oranını görmekteyiz. Almanya için küçük iniş çıkışlar dışında bir değişiklik gözlemlenmezken, ülkelerin tamamında ve Fransa'da da krizi takip eden dönemde büyük oranlarda düşüş gözlemliyoruz.

Avrupa, ABD'ye göre bankacılık ve iç borçlar anlamında da daha kritik durumdaydı. Avro bölgesi ülkeleri, İngiltere ve ABD'nin aksine, ekonomilerini krizden çıkarmak için tetikleme konusunda daha yavaştılar. Üstelik krize çok düzensiz bir şekilde yakalanmışlardı. Avro bölgesinde gözlenen ve artan bütçe açıkları hükümetlerin müsrif tutumları yüzünden değil doğrudan üretimin ve yatırımın aniden düşmesi yüzünden içsel olarak yaratılmaktaydı. Olası bir likidite krizi esnasında kurtarma planları finansal piyasalardan temin etmekle sınırlı kalan ekonomiler, bu işi normalde olduğundan daha pahalıya gerçekleştirebiliyorlardı. Nitekim Avro krizi sırasında ticari bankalar, Avro bölgesinin periferi ülkelerine olan fon akışını kıstılar ve adeta uçuşa geçen risk primlerini karşlamak için, çok yüksek faiz talep ettiler. Üye ülkelerin uygulamaya koyduğu genişletici maliye politikaları ticari bankalara bir nefes aldırmış olsa da, durgunluk nedeniyle vergi gelirleri de düşünce, ülkeler devlet borcu krizi yaşadılar. Ne gariptir ki, sıkı maliye politikası 
ve ücretlerde kısıntıya gidilmesini öneren ve uygulamayan hükümetleri fon akışını kesintiye uğratmakla tehdit eden de, IMF ve Avrupa Komisyonu'nu tarafindan desteklenen de aynı bankalard1 (Lucarelli, 2011: 211).

Ortak bir maliye rejimi olmaksızın, Avrupa bankacılık sistemi, üye ülkelerin devlet borcu iflası risklerine açıktı. AMB (Avrupa Merkez Bankası) son "piyasa yapıcı" olarak hareket ediyordu. Bu durum, olası bir likidite tuzağı durumunda yenilenmeyen kredi verme olanakları olmasa bile likiditeleri arttırıp, bilançolarını düze çıkarma imkânı veriyordu. Fakat bütün bunlar olurken siyasi ve sosyal maliyetler, çevrede açık veren ülkelerin çalışan kesimleri tarafından karşılanıyordu.

Tarihsel bağlam ve kurumsal çerçeveyi anlamak, Avrupa'nın içine düştüğü krizi anlamakta çok kritik rol oynar. Avrupa'da uzun süren bu yapısal krizin, asıl itibariyle otuz yıldır uygulanmakta olan neoliberal deflasyon politikalarının bir sonucu olduğunu söylemek zor değildir. Maastrich Anlaşması ve onun getirdiği "kutsal" yakınsama kriterleri ve devamında 1997 İstikrar ve Büyüme Paktı, mevcut krize giden yolun yapı taşlarıdır. AMB'nın kendine has özellikleri ve Almanya'nın sürekli olarak neomerkantilist rekabetçi deflasyon politikaları uygulaması avro bölgesinde kendi kendini güçlendiren ve neredeyse geri döndürülemez bir hal alan düşüş ve resesyona yol açmıştır (Lucarelli, 2011, Lapavitzas, 2010, et all ).

1992 yılında hayata geçirilen Maastrich Anlaşması hem Avrupa Parasal Birliğini'nin ve hem de AMB'nın kurumsal düzenlemesini yapmaktadır. Siyasi birliğin olmadığı bir durumda, 1999 yılında avronun doğuşu, tamamlayıcı bir maliye çerçevesi ya da hazinesi olmayan bir merkez bankası yaratmıştır. Anlaşmanın getirdiği, dar ve rastgele belirlenmiş maliye kriterleri bütün avro bölesinde deflasyonist bir etki doğurmuş ve bu dar mali ceket bölgenin süregiden daralma ve artan işsizlik oranlarının başlıca belirleyeni olmuştur. (Lucarelli, 2011, Lapavitzas, 2010, et all).

Diğer yandan, döviz kurları, Döviz Kuru Mekanizmasına (Exchange Rate Mechanism) bağlanır bağlanmaz, çevre ülkelerin kendi paralarını aşındırarak rekabet güçlerini koruma ya da arttırma araçları ortadan kalkmıştır. Üstelik avro bölgesi için ortak bir döviz kuru politikası ya da açık piyasa işlemleri uygulanmadığı için, döviz kurları tamamen piyasa güçleri tarafindan belirlenmeye terkedilmiştir. (Lucarelli, 2011: 214).

Merkez Bankacılığının temel prensiplerinden biri olan son borç verme mercii fonksiyonu açıklama kabul etmez bir şekilde, Maastrich anlaşması ile yasaklanmıştır. Yani, olası bir devlet borcu krizi ortaya çıkarsa Avrupa Merkez Bankası üye ülkeleri kurtarmak adına herhangi bir girişimde bulunmaktan men edilmiştir. Anlaşmanın AMB'sına getirdiği kısitlar, avro bölgesinde enflasyonist farklılıkların devam etmesi nedeniyle, bankanın tutarlı ve aynı araçları kullanan para politikaları uygulamasını da engellemiştir. Bunun yerine herkes için aynı reçetenin uygulanması, ülkeler arasında devam eden enflasyon farklılıklarını daha da alevlendirmiştir (Grafik 4.1). Bütün bölge için AMB tarafından tek 
bir faiz haddi ilan edilmesi (Grafik 4.2), parasal aktarma mekanizması aracıllğıyla, yüksek enflasyon olan ülkelerde görece daha düşük faiz oranlarının tecrübe edilmesine neden olmuştur. Sonuç olarak da, İspanya, Portekiz ve Yunanistan gibi açık veren ülkelerin piyasalarında varlık fiyatlarında patlamalar gözlenmiştir (Grafik 4.4) (Lucarelli, 2011: 216).

\section{Grafik 4.2}

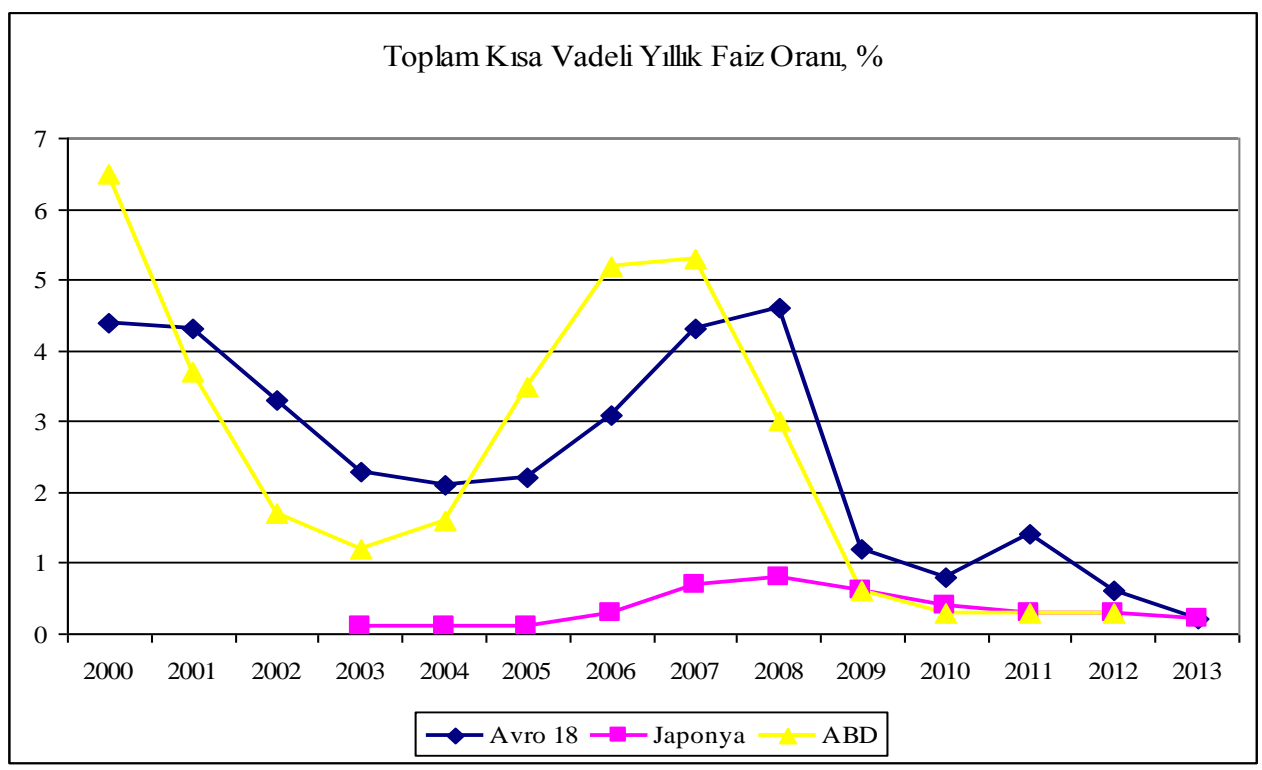

Kaynak: <data.oecd.org>, 23.02.2014.

Diğer yandan, Avrupa krizi için geleneksel neoklasik bir açıklama şöyle olabilir: Hükümetlerin aşırı mali harcama yapması durumunda bir noktada iktisadi ajanlar hükümetin borçlarını ödeyebileceğine olan güvenlerini kaybederler. Aşırı harcama aynı zamanda enflasyonist baskılar yaratır ve bu nedenle uluslararası rekabet gücünde azalma görülür (Yani rekabet gücü kaybının asıl sebebi ortak para birimine geçerek döviz kuru aracını kaybetmek değildir). Bir başka deyişle, geleneksel bakışa göre ödemeler dengesinin durumu maliye politikasındaki yanlışlıklar nedeniyle ortaya çıkmıştır.

Geleneksel açıklamalar mali serbestleşmenin krizlere olan etkisini de ikincil bir konuma yerleştirirler. Eğer hükümetler bütçelerini dengede tutup, refah devleti yaratma cazibesine kapılmasalar, kamu genişlemesinden doğan aşırı özel harcamalar bu denli çok olmazdı. Bankalar ve yatırımcılar da risklerin daha ayırdında olurlardı. Bu nedenle, Avrupa konusunda yapılması gereken oyunu biraz sertleștirmekti. Bir başka deyişle, periferi ülkeler Maastrich Anlaşmasının sınırladığı yere kadar harcamalarını düşürmeli ve refah devleti 
uygulamalarını da gözden geçirmelidir. Mali disipline uyulması halinde mali bir tetiklemeye ihtiyaç duymadan doğal işsizlik oranını yaşayarak ekonomi tekrar rayına girecektir. Bu bakış açısı akademide de, politika uygulayıcıları arasında da hâlâ kabul görmektedir.

\section{Grafik 4.3}

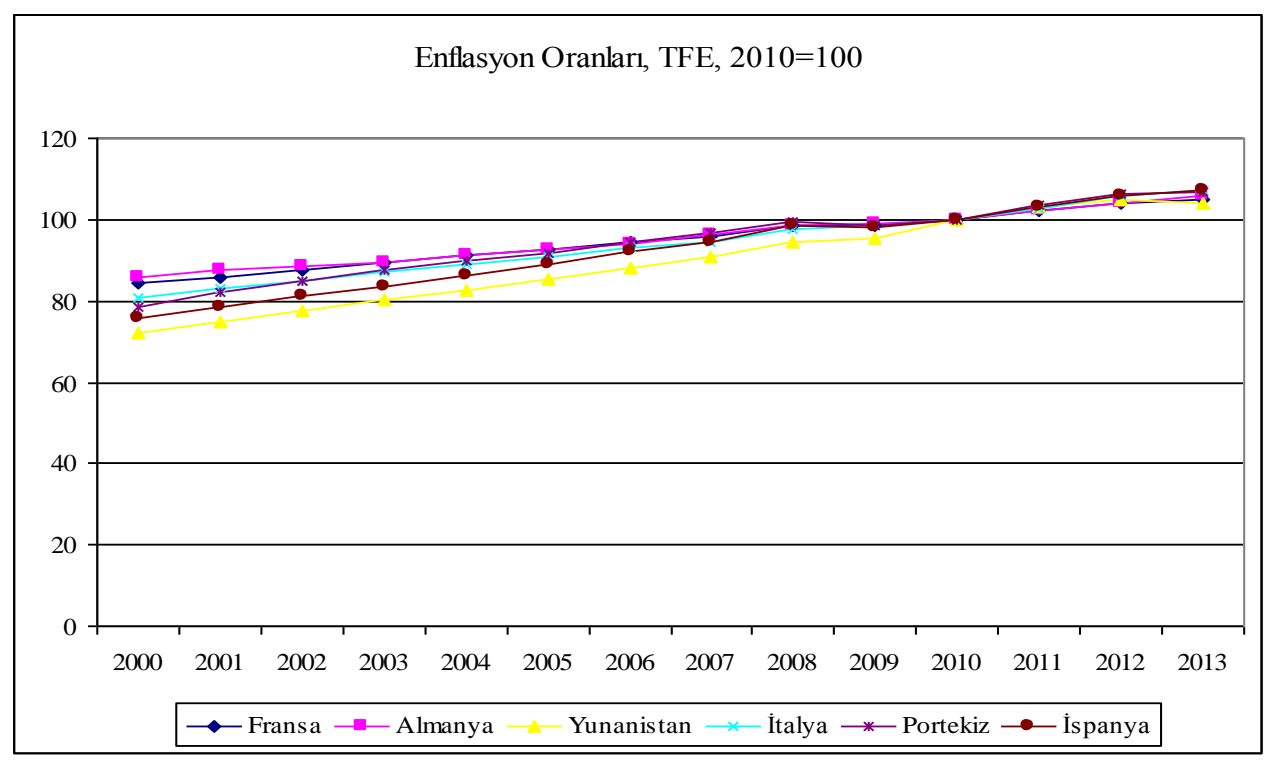

Kaynak: 〈data.oecd.org〉, 23.02.2014.

Vernengo ve Peres-Kaldente'ye (2012) göre ise avroya geçiş ve onun diş rekabet gücü üzerindeki etkisi, para ve maliye politikalarına olan etkisi ve mali serbestleşme krizin altında yatan temel nedenlerdir. Kriz bizzat Avrupa ekonomik modelinin yapısından kaynaklanmaktadır. Modele göre merkez ülkeler "komşunu yoksullaştır" politikaları uygulayarak ihracatlarını arttırırken, periferi ülkelerde borç birikmesine neden olmaktadır. Bu dengesiz gidişat 2007-2008 küresel krizinde daha da pekişmiş ve sürdürülemez bir hal almıştır. Dolayısıyla mali kriz, krizin nedeni değil sonucudur. 


\section{Grafik $4.4^{7}$}

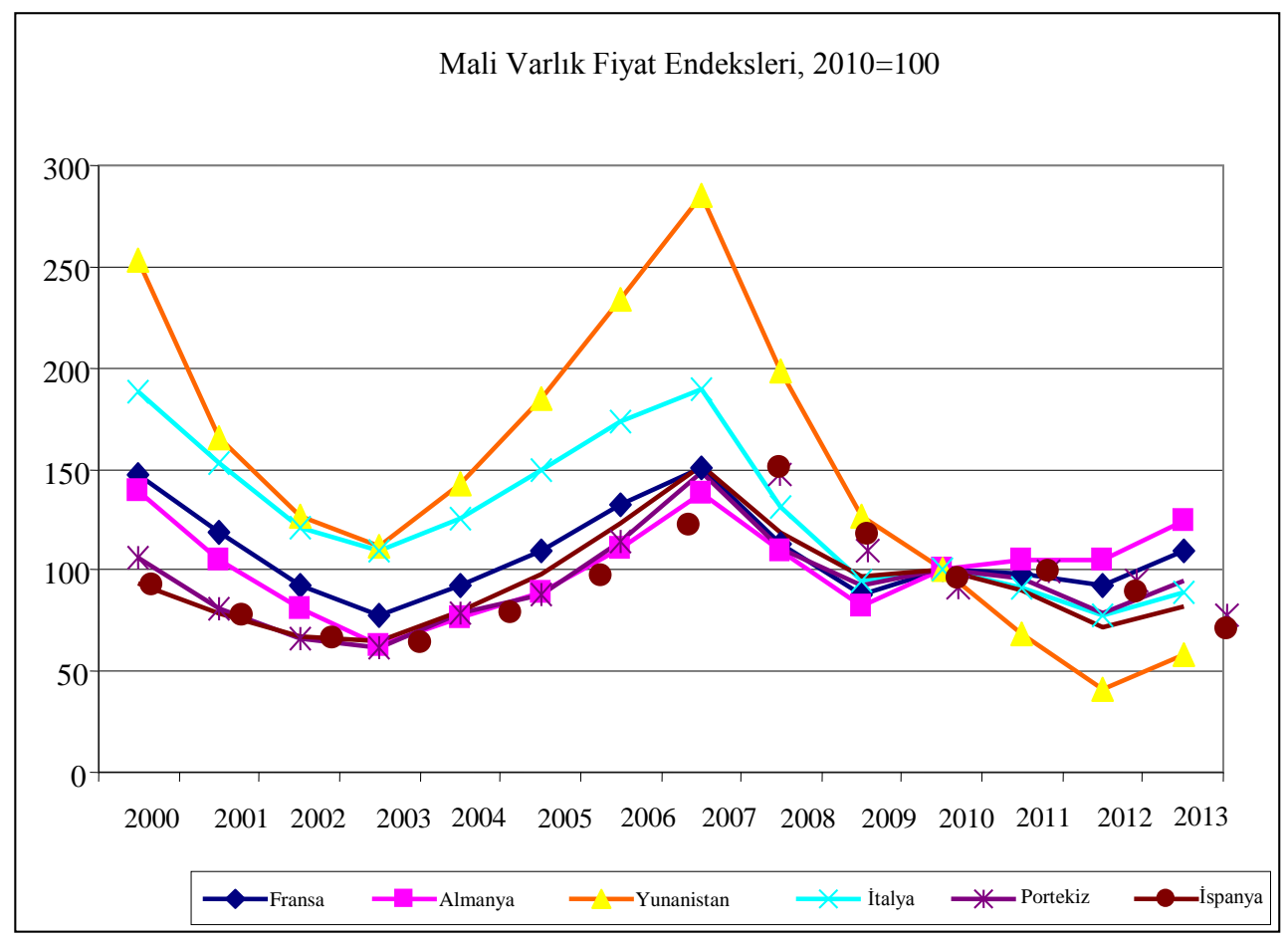

Kaynak: <data.oecd.org>, 23.02.2014.

7 Burada dikkate alınan mali varlıklar, ulusal ve uluslararası borsalarda işlem gören şirket hisseleridir. Indeks, bu hisselerin günlük kapanış fiyatlarının aritmetik ortalaması kullanılarak hesaplanmaktadır. 


\section{Grafik 4.5}

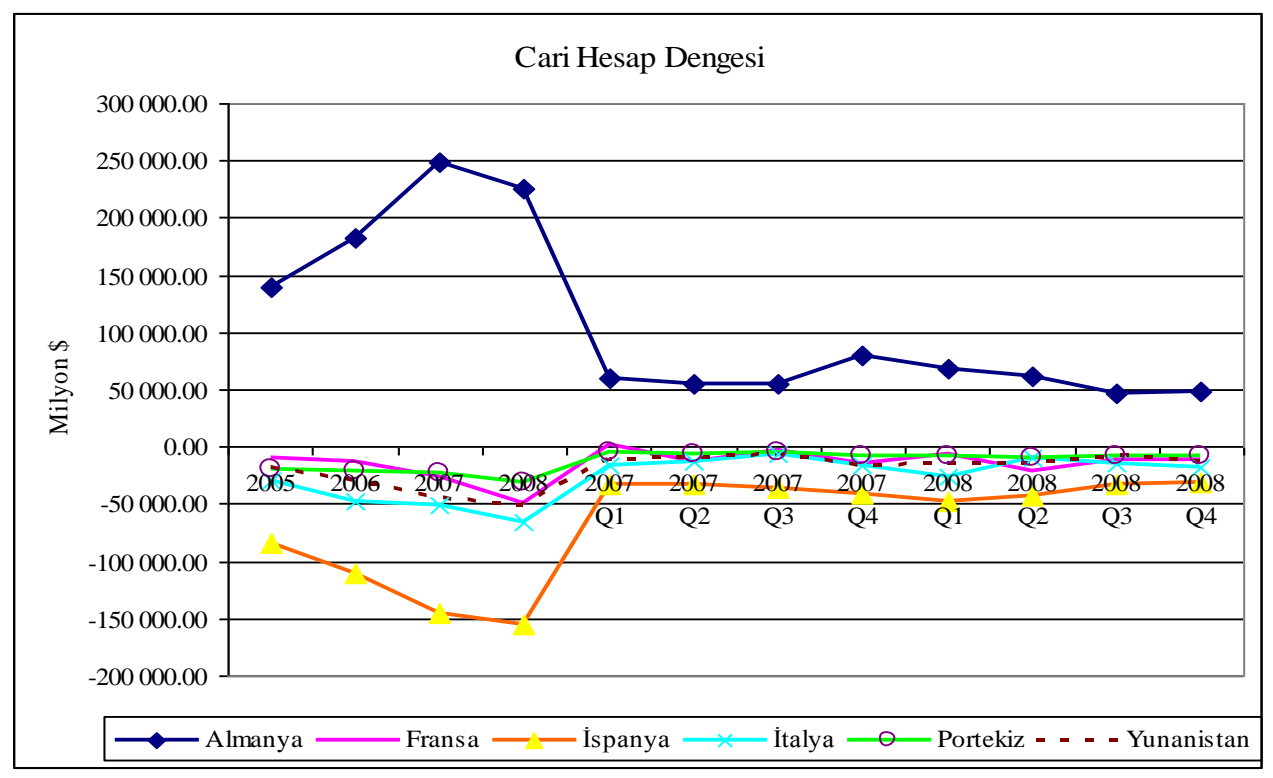

Kaynak: 〈www.imf.org〉, 25.02.2014.

Görüldüğü üzere, ABD’de patlak veren kriz Avro bölgesine sıçramadan önce bile Almanya merkez ülke konumunda sistematik cari fazla verirken, Fransa'nın da içinde bulunduğu güney Avrupa grubu sistematik açık veriyordu (Grafik 4.5). Krizin etkilerinin giderilmesi için alınan sert tedbirlerin bile 2013 yılına kadar bir düzelme sağlayamadığı Grafik 4.6' da görülmektedir. 


\section{Grafik 4.6}

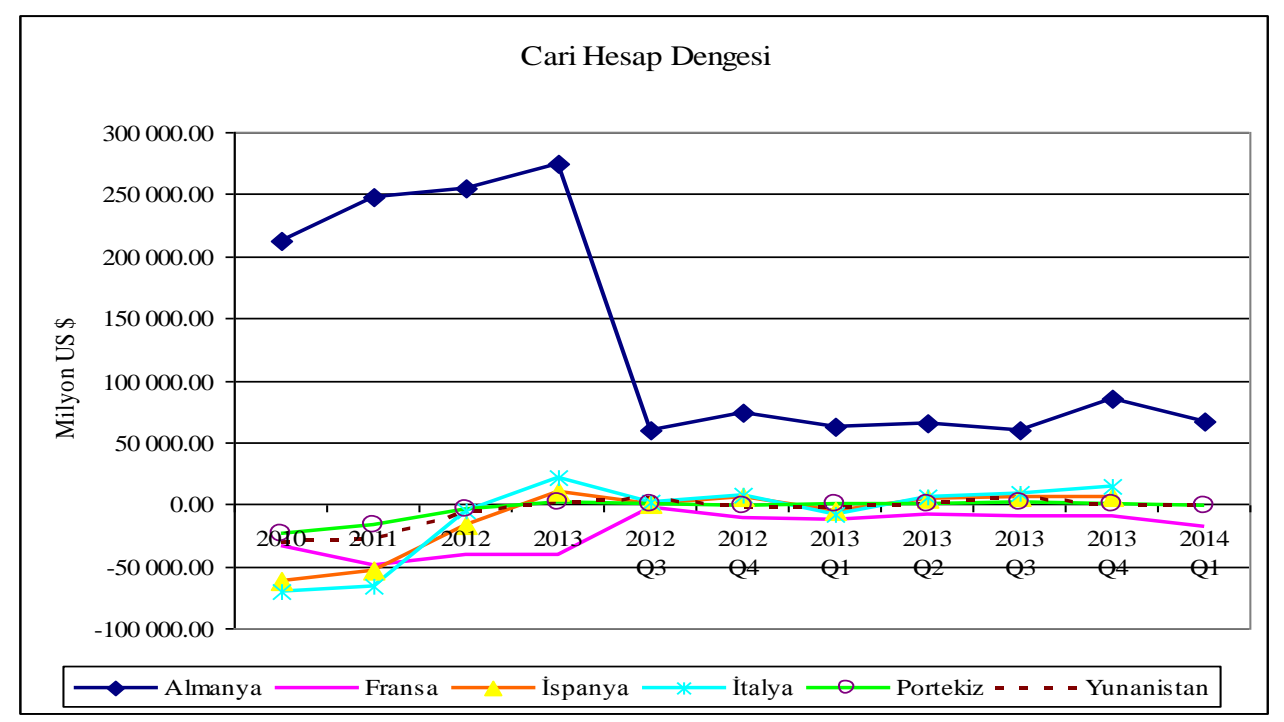

Kaynak: 〈www.imf.org>, 25.02.2014.

Avroya geçişten sonra ortaya çıkan önemli sorunlardan biri, kamu borcunun egemen otorite tarafından kontrol edilemeyen bir para birimi cinsinden yaratılmış olmasıydı. Üstelik Avro üyeleri paralarını birbirlerine göre değersizleştiremediklerinden tipik olarak para birimi krizlerinde ortaya çıkan durum (yerli paranın değer kaybetmesi) da gerçekleşmiyordu (Pérez-Caldentey and Vernengo, 2012: 12).

1 Ocak 2002'de avroya geçiş, önceden Maastrich Anlaşması'nda belirlenen yakınsama kriterlerine uyumun gerçekleşmesi ile oldu. Bu kriterler; enflasyon, döviz kuru ve faiz oranları ile mali dengenin yakınsamasını kapsıyordu. Döviz kuru yakınsaması koşulu, tek paraya geçişten önce döviz kuru manipülasyonuyla birliğe girerek, rekabet gücü sağlama politikasını engellemek için getirildi. Enflasyon oranı ve bütçe dengesinin yakınsaması ise parasal birlikte görülebilecek olası bir enflasyonist baskıyı engellemek için düşünülmüştü. Mali dengeden kasıt bütçe açığının GSYH'nın en fazla \%3'ü olması idi ve 1997'de Büyüme ve Ístikrar Paktı ile belirtilmişti. Faiz hadlerinde yakınsama ise birliğe girmeden önce arbitraj olanaklarını kısıtlayarak sermaye kayıp ve kazançlarını azaltmayı hedefliyordu. Ancak ayrı bir hedef olarak gözetilmesi gereksizdi çünkü tek paraya geçip, ortak kur ve serbest sermaye hareketi olunca zaten nominal faizler yakınsayacaktı ve öyle de oldu. 
Avrupa birliği içinde mali mevzuat ortaklaştırılıp tek para geçilince, ülkeler arası sermaye hareketlerinin hacminde büyük bir artı̧̧ gözlendi. Bankalara arası bilateral işlemler avroya geçişten sonra \%40 arttı (Pérez-Caldentey and Vernengo, 2012: 16).

Kısaca söylemek gerekirse, Avrupa Parasal Birliği’nin tasarımı, açık veren ülkelerin mali açıklarını parasallaştırmalarına izin vermiyordu. Dahası, ticari bankaların refinansman işlemlerinde kullanacağı banknotları basma hakkı Avro Sistemi Konsülü'nde bulunuyordu. $\mathrm{Bu}$ nedenle, konsül sadece refinansman faiz oranını ve avro sistemindeki likidite miktarını belirlemekle kalmıyor, aynı zamanda merkez bankası parasının farklı ulusal merkez bankaları arasındaki tahsisini de (banka sermayelerine katkıları oranında) belirliyordu. Avrupa parasal birliğine üye olmak, ulusal merkez bankalarını baz para karşıllğında hükümet tahvili satın alma gücünden mahrum bırakıyordu. Sonuç olarak, ulusal merkez bankalarının senyoraj hakları da AMB'sına devredilmişti. Devlet borçları (soverign debts) artık ulusal para ya da kendi merkez bankasının basabildiği para cinsinden olmadığından, olası bir finansal krizde hükümetin borçlarını hiçbir şekilde ödeyememe ihtimali vardı. Ticari bankaların ve bankalararası piyasanın finansal riskleri değerlendirme konusunda merkez bankalarından daha başarılı olduklarına olan neoliberal inanç Maastrich Anlaşmasının temel dayanağıydı. Bu çerçevede hükümetlerin borçlarını finansa etmesinin tek mecraı finansal piyasalardı. Sonuç olarak, Avrupa Parasal Birliği'nin mevcut neoliberal mimarisi altında maliye politikalarının fonksiyonel finansman ilkelerine göre düzenlenip uygulanması ortadan kalkmış oldu. (Keynesyen maliye enstrümanlarından mahrum kaldılar). Geri ödeyememe durumunda zayıf perifer ülkelerin önünde iki acı seçenek vardı: Ya iflas edip avro parasal birliğinden çıkacaklardı ya da çok sıkı kemer sıkma politikaları uygulayacakları. Şu ana kadar başta Yunanistan olmak üzere hepsi ikinci yolu seçti (Lucarelli, 2011).

Paradoksal bir durum olarak, avroya geçiş, Almanya'nın ülkeye giriş yapan ABD dolarını sterilize etme olanağını elinden almıştı. Bu da kuru yükselttiği için ihracat rekabet performansını kötü etkiliyordu. Avronun değer kazanması Almanya'nın neomerkantilist politikalar ve ücret kısıntısı uygulamasını daha da yoğunlaştırdı (Lucarelli, 2011, Bellofiore Garibaldo ve Halevi, 2010 ve Lapavitzas, 2010, et all, ).

Başta Almanya olmak üzere, fazla veren ülkelerin genişletici politikalar uygulamak yerine, neomerkantilist politikalara sağdık kalmaları bütün avro bölgesinin efektif talebini düşürüyor ve ekonomiyi daraltıyordu. Bu anlamda, Almanya'nın açık veren ülkeleri müsriflikle suçlaması da kendi içinde çelişik bir söylemdi çünkü Almanya o açıklar sayesinde fazla veriyordu. Ancak Almanya dışındaki ülkeler iç talebin daralmasını telafi edecek bir dış talep yaratma potansiyeli taşımıyordu. Ülke içinde kemer sıkma ve düşük ücret politikasının varlığı, yabancı firmaların Almanya'ya girişine engel oluyordu. Alman endüstriyel gruplarıyla büyük bankalar arasındaki yakın bağlantılar bahsedilen neomerkantilist politikaları daha da güçlendiren bir faktördür. 
Almanya'nın rekabetçi deflasyon politikası, rekabet güçlerini kaybetmemek için ülkeleri de benzer politika uygulamaya mecbur bırakıyordu. Ancak Almanya başta olmak üzere fazla veren ülkeler hükümet borcu basarken düşük faiz oranlarına tabi olurken, açık ülkeleri iç borç finansmanında hep yüksek faiz, kredi notlarının düşmesi ve daha fazla borç ödeyemez duruma düşme riski ile karşı karşıyaydı.

\section{Dibe Doğru Yarış: Dâhili Devalüasyon}

AMB para politikasını, Maastrich Anlaşması da maliye politikasını belirlemiş iken, Almanya'nın ücret baskılaması ile karşı karşıya olan perifer ülkelerin tek çıkar yolu, kendi ücretlerini ve fiyatlarını çok daha beter baskılamaktı. Bu politikanın literatürdeki karşılığ1 'dâhili devalüasyon'dur. (Mazier ve Petit, 2013, Armingeon ve Baccaro, 2012, Wisbrot ve Ray, 2010). Aslında kriz ortaya çıkmadan da, bizzat yaşanırken de kendi rekabet güçlerinin daha ilerisindeki bir merkez bloğuna karşı gerçek değerinin üstünde bir ortak paraya maruz kalmış ülkelerin uygulayabileceği yegâne politika dâhili devalüasyondu. Ülkeler merkezle yakınsamak şöyle dursun, aslında kendi aralarında ve merkeze karşı dâhili devalüasyonun seviyesi üzerinden rekabet ediyorlard1.

AMB ve Avrupa Komisyonu 2000'li yıllarda, daha sıkı bir finansal bütünleşme stratejisinin dâhili sermaye transferleri yoluyla istikrarı tesis edeceğini savunuyordu. Bölge içi krediler ve sermaye hareketlerinden doğan kazançların tatmin edici bir istikrar mekanizması olması bekleniyordu. Ancak, gerçeklik kendini merkezde tekrarlayan fazla ve çevrede de tekrarlayan açık olarak tesis ettiğinde, daha sıkı bütünleşmenin sorunları arttırdığı apaçık ortaya çıktı (Mazier ve Petit, 2013: 514). Dolayısıyla elde kalan yegâne ayarlama mekanizması -göreli fiyat değişiklikleri- devreye sokuldu. Sistematik açık veren ülkeler ücretleri ve dolayısıyla fiyatları baskılayabilirlerdi ve bunu yaptılar. Fakat birbirleriyle yoğun ticaret ilişkisi içinde olan ülkelerin böyle bir yolu seçmesi, kısa vadede bütün ülkeler grubunun toptan daha kötü bir sonuçla karşılaşmasını kaçınılmaz kılıyordu. $\mathrm{Bu}$ sebeple, dahili devalüasyon ancak uzun vadede ve birbirlerinden bağımsız ülkeler için uygulandığında bir çıkış yolu olabilmesi imkânlıydı.

Hatırlanacağı üzere, sözünü ettiğimiz baskılama ya da yaygın adıyla kemer sıkma politikaları 80'lerin ikinci yarısında Fransa'da ve birleşme sürecinde Almanya'da uygulanmıştı. Yapısal sorunları baki kalan Fransa'da sonuç düşük enflasyon, yavaş büyüme ve yaygın işsizlik olurken, Almanya süreçten maliyet avantajları yaratabilmiş sağlam bir ekonomi olarak çıkmayı başarmıştı (Bellofiore, 2013, Kuruç, 2011). Dolayısıyla, uygulayıcıların yerel dinamiklerine bağlı olarak farklı sonuçlar doğuran kemer sıkma politikalarını uygulama sırası Avrupa'nın ülkelerine gelmişti. Özelleştirilmiş finansal Keynesçiliğin yarattığı genişleme dalgasının etkisiyle ABD’den Avrupa'ya sıçrayan ve birliğin kendi kırılganlıklarıyla daha da pekişen krizden kurtulmanın aracı olarak kamu harcamalarının kısılması, sendikaların zayıflatılması, ücretlerin düşürülmesi ve hızla yükselen ve yaygınlaşan işsizlik sorununa göz yumulması Avrupa 'piyasalarının' yegâne umuduydu. Ancak, ortaya çıkan sonuç yüksek işsizlik oranları (Grafik 5.1) yanında 
düşürülmüş maliyetlere rağmen varlığını koruyan üretim daralması (Grafik 5.2) ve yavaş büyümeydi (Kitromilides, 2011, Arestis ve Pelagidis, 2010).

\section{Grafik 5.1}

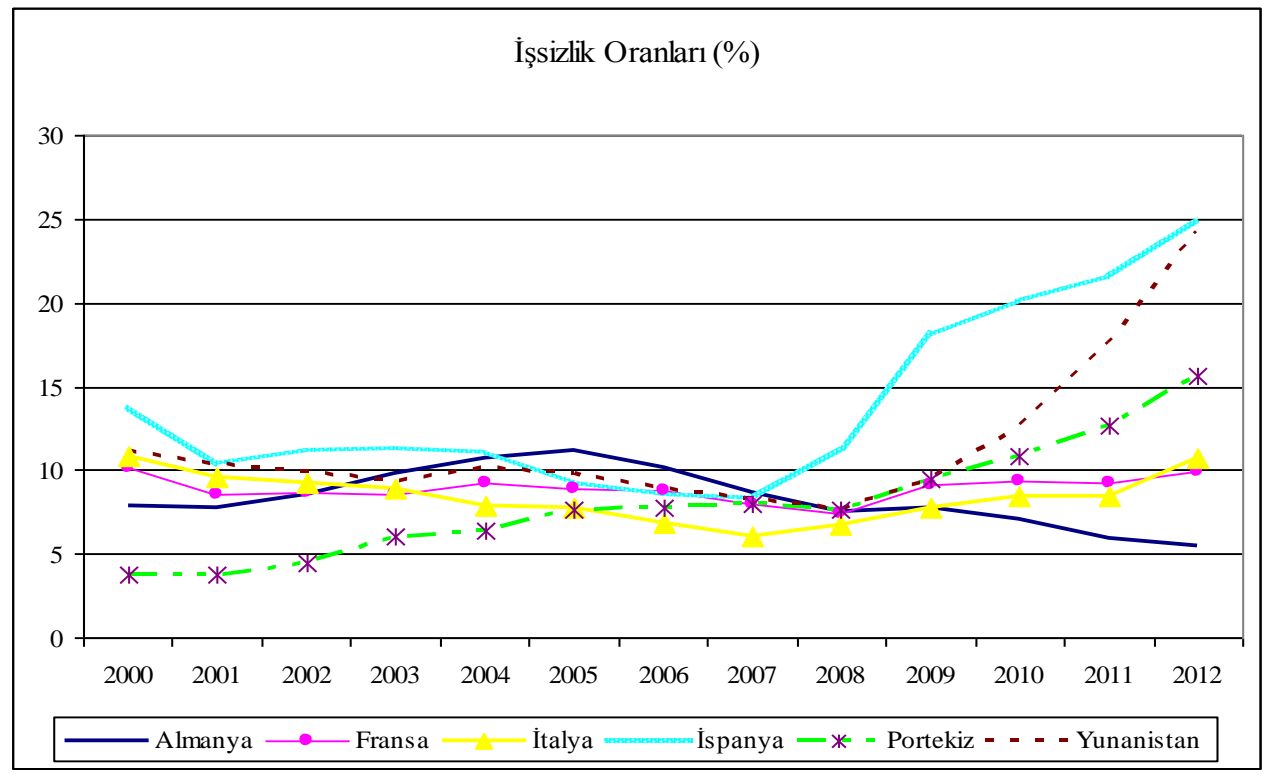

Kaynak: 〈www.ilo.org〉, 24.02.2014. 


\section{Grafik 5.2}

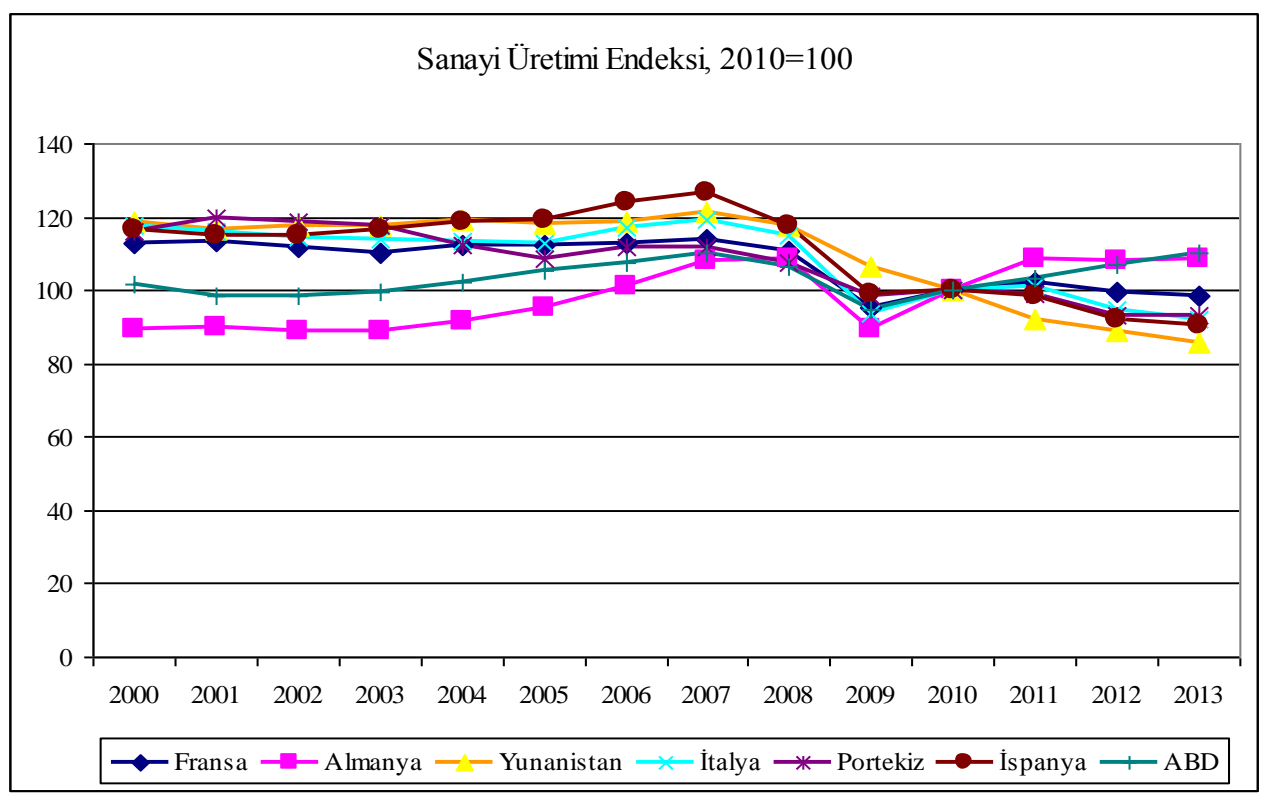

Kaynak: <data.oecd.org>, 24.02.2014. 


\section{Grafik 5.3}

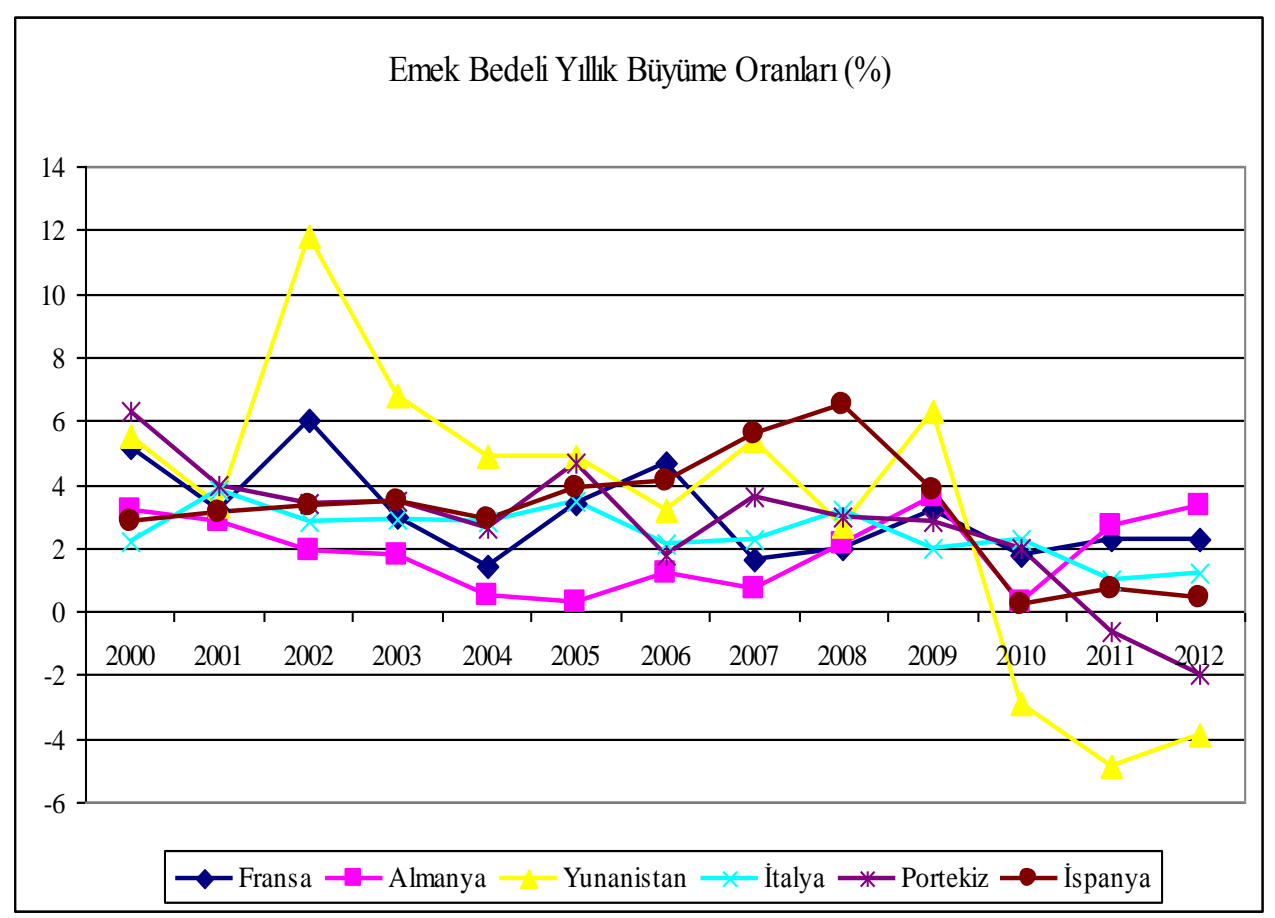

Kaynak: <data.oecd.org>, 24.02.2014.

Grafik 5.3'te çalışılan saat başına elde edilen alım gücüne işaret eden emek bedeli rakamlarının yıllık büyüme oranlarını gözlüyoruz. Özellikle parasal birliğe geçişten sonra değişkenin seçilen ülkeler içinde en yüksek değerine ulaşan Yunanistan'ın kriz sonrası yaşadığı daralma çok dikkat çekicidir. O’nu Portekiz ve İspanya takip ederken, Fransa ve İtalya aşırı düşmeden toparlanmayı başarmıştır. Bu rakamların yorumlanmasında ülkelerin uyguladığı dahili devalüasyon politikalarının 'başarı' düzeylerinin belirleyici olduğunu düşünmekteyiz.

Ortodoks literatürde parasal birliğin ‘özel durumu' olarak sunulan Yunanistan örneğine daha yakından bakılırsa, dahili devalüasyonun sınıfsal pozisyonunu daha net olarak gözlemek mümkündür. Avro krizine geleneksel yaklaşımla cevap veren literatürde özellikle Yunanistan'da yaşanan yıkımın 'ev-yapımı' olduğu iddia edilir. Geleneksel olarak daha az

8 Emek bedeli (labor compensation) yıllık büyüme oranı: Özel tüketim alım gücü paritesinin toplam çalışılan saate bölünmesinden elde edilen saatlik emek bedelinin yıllık büyümesi şeklinde hesaplanmaktadır. 
demokratikleşen ve ekonomisinde himayeci, kayırmacı ilişkilerin yoğun olarak gözlendiği ülke, yüksek ticaret ve kamu açıklarıyla, ezelden ebede 'müsrif' bir ekonomi olarak nitelenir. $\mathrm{Bu}$ teze göre, rant kollamacılığın bir kültür olduğu ve bu nedenle himayeci devlet ve özel kurumların daha da yaygınlaştığı bu 'yanlış' ekonomi, belki düzelir, tasarruf etmeyi öğrenir, demokratikleşir diye birliğe alınmıştır. Ancak, ne yazık ki, beklentiler gerçekleşmemiş ve sonuç tamamen içsel olarak yaratılmış bir yıkım olmuştur (Markantonatou, 2012: 416).

1995-2008 dönemi Yunanistan'ına farklı bir pencereden bakarsak, sözü edilen evrede emek üretkenliklerinin ücretlerden daha yüksek oranlarda arttı̆̆ına tanık oluruz. Birlikten gelen fonlarla yapılan teknolojik yatırımlarla izah edilen bu üretkenlik artışlarının, ihracat performanslarına neden yansımadı ̆̆ sorusu ise Avro' ya maruz kalan diğer ülkelerde de olduğu gibi bu spesifik coğrafya için kurun gereğinden fazla değerli olduğu gerçeğiyle yanıtlanır. Bu dönemde ücretlerin kademeli olarak, Avrupa Birliği ortalamasına yaklaşması bile Yunanistan'ın çalışan başına gelir ortalamasında tüm listenin en sonunda yer almasını engelleyememiştir. Bunun yanında, 1990'lar ve 2000'ler emek piyasalarına yoğun olarak sermaye-yanlısı müdahalelerin olduğu yıllar olmuştur. Kamuda ve özelde yarı zamanla çalışma ölçeğinin genişletilmesini sağlayacak düzenlemelerin yapılması, özel sektörde toplu sözleşme koşullarını ortadan kaldırılması, işverenlerin yapmak zorunda oldukları sosyal güvenlik katkılarının düşürülmesi, işten atmalarda aylık maksimum rakamların yükseltilmesi, bizzat devlet eliyle geçici iş bulma ajansları açma lisansları verilmesi, emekçilerin sosyal ve hukuksal korunmalarını sağlayacak düzenlemelerin sürekli olarak aşındırılması ilk bakışta göze çarpan gelişmelerdir. Diğer yandan, kamunun sermaye yanlısı tutumunu bir kez daha cömertçe sergilediği bir başka husus da vergilendirme konusudur. 2008 yılına kadar, kâr gelirlerinin vergi oranları düşürülürken, ücret gelirlerinin vergi oranları arttırılmıştır. (Markantonatou, 2012:423). Dolayısıyla, krizden sonra kamuda yar1zamanlı çalışmayı daha da yaygınlaştıran ve toplu sözleşme kavramını ortadan kaldıran, yoğun özelleştirmelerle geniş halk yığınlarının eğitim ve sağlık erişimlerini alabildiğine kısıtlayan tedbirlerle pekişen dahili devalüasyon, ortak para-yüksek kur kapanına kısılmış ekonomiler için bedeli emekçi kesimlere ödetilen acılı bir çıkış yolu olarak tasarlanmıştır.

Öte yandan, dâhili devalüasyonun birer 'başarı' hikâyesine dönüştüğü örneklerden de bahsetmek mümkündür. Avro bölgesine çok daha geç katılan (2011) Baltık ülkeleri avroya bağlı bir currency board uygulamasına tabiiydiler. Yüksek cari açık ile birlikte bütçe açıkları ile yüz yüze oldukları için büyük ölçekli dahili devalüasyon uygulamasına gittiler. Örneğin Estonya'da üretim \%10 ile \%20 arasında değişen oranlarda daralırken, ücretler ve fiyatlar düşmüş, işsizlik dramatik olarak artmıştır. Bunun yanında ise cari hesaptaki açık giderilmiş ve özellikle memur maaşlarındaki kısıntılar gibi bütçe daraltıcı politikalar ile bütçe açığı kapatılmıştır. 2011 yılı ile birlikte ihracattaki artışla iktisadi büyüme ciddi oranda hızlanmıştır (Mazier ve Petit, 2013: 518).

Dahili devalüasyon uygulamalarının Baltık ülkelerinde işleyip de Yunanistan, İspanya ya da Portekiz'de beklenen sonuçları doğuramamasının çeşitli nedenleri vardır. Şöyle ki, görece yeni kurulmuş küçük yüzölçümlü Baltık ülkelerinin emek piyasaları 
esnektir, iç piyasaları dardır ve dünya ile alışverişleri daha yüksektir. Böyle bir iktisadi yapının, dışarıda gerçekleşen rekabet gücü farklılaşmalarına cevap vermesi daha imkânlı olmuş, üstelik iç piyasanın darlığı fiyat ayarlamalarının daha maliyetsiz ve etkin olmasına yol açmışırı. Diğer yandan, emek piyasalarının daha karmaşık sosyal yapılara sahip olduğu güney Avrupa ülkelerinde iç pazarın genişliği fiyat değişikliklerini daha maliyetli hale getirmiştir (Mazier ve Petit, 2013: 518).

\section{Grafik 5.4}

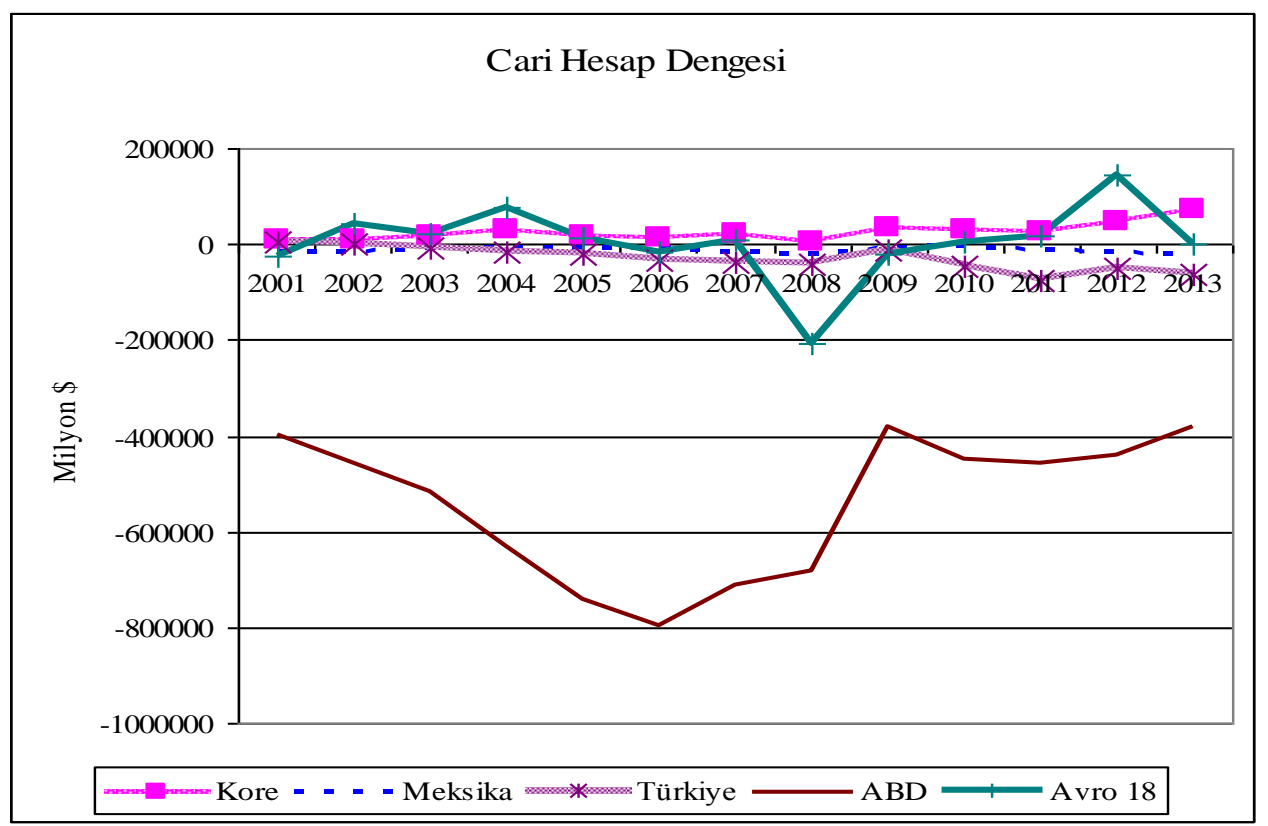

Kaynak: <data.oecd.org>, 24.02.2014.

Özetlemek gerekirse, bütçe kısıntılarıyla desteklenmiş dahili devalüasyon hamlelerinin iç pazarı geniş ülkelerde beklenen sonuçları ancak uzun vadede verebileceği, kısa vadede ise büyüme rakamlarını gerileterek sadece uygulandığ 1 ülkede değil, onunla ticaret ilişkisi olan tüm bölgeler için daralmayla sonuçlanacağ 1 şu ana kadar yaşanmış tecrübelerde görülmüştür. Üstelik beklenen sonucu elde etmek için yapılan fedakârlık son derece asimetrik olduğu için, toplumsal hoşnutsuzluk ve direnişle karşılanması da kuvvetle muhtemeldir.

Aslında Avro bölgesi bir bütün olarak değerlendirildiğinde ticaret performansının çok da fena bir gidişatı yoktur ve Avrupa Birliği hükümetlerinin bütçe açıkları bir çok OECD ülkesininkinden daha azdır (Grafik 5.4 ve 5.5). Dolayısıyla, küresel anlamda bakılırsa Avro 
denge paritesine yakın bir hatta seyretmektedir. Olası bir devalüasyonun Avrupa'nın krizi atlatma şansını arttıracağı açıktır. Ancak, böyle bir hamle sıfır toplamlı bir oyundur çünkü Avrupa'nın ticaret partnerleri Avro devalüasyonundan olumsuz etkilenecektir. Diğer yandan, Avrupa parçaları gözetilerek ele alınırsa farklı ülkeler için farklı döviz kuru sapmaları görülecektir (Jeong 2010'dan aktaran Mazier ve Petit, 2013: 515). Jeong'un (2010) çalışmasında, avronun İtalya hariç güney Avrupa ülkeleri için aşırı değerli olduğu ve özellikle Almanya ve diğer kuzey Avrupa ülkeleri için de değerinin altında olduğu bulgularına ulaşılmışıtır. Çalışmanın tahmin sonuçlarına göre 2010 yılında İspanyol Avrosu $\% 15$, Yunan Avrosu \%19, Portekiz Avrosu \%25 oranlarında aşırı değerli iken, Alman Avrosu \%22 oranında gerçek değerinin altında seyretmekte idi (Mazier ve Petit, 2013, 515). Döviz kurunda durum böyle iken Avro çatısının dağılması durumunda Yunanistan, İspanya ve Portekiz'in şiddetli bir devalüasyon yaşaması ve bunun karşılığında da Alman parasının benzer oranlarda değerlenmesi olası görünmektedir.

\section{Grafik 5.5}

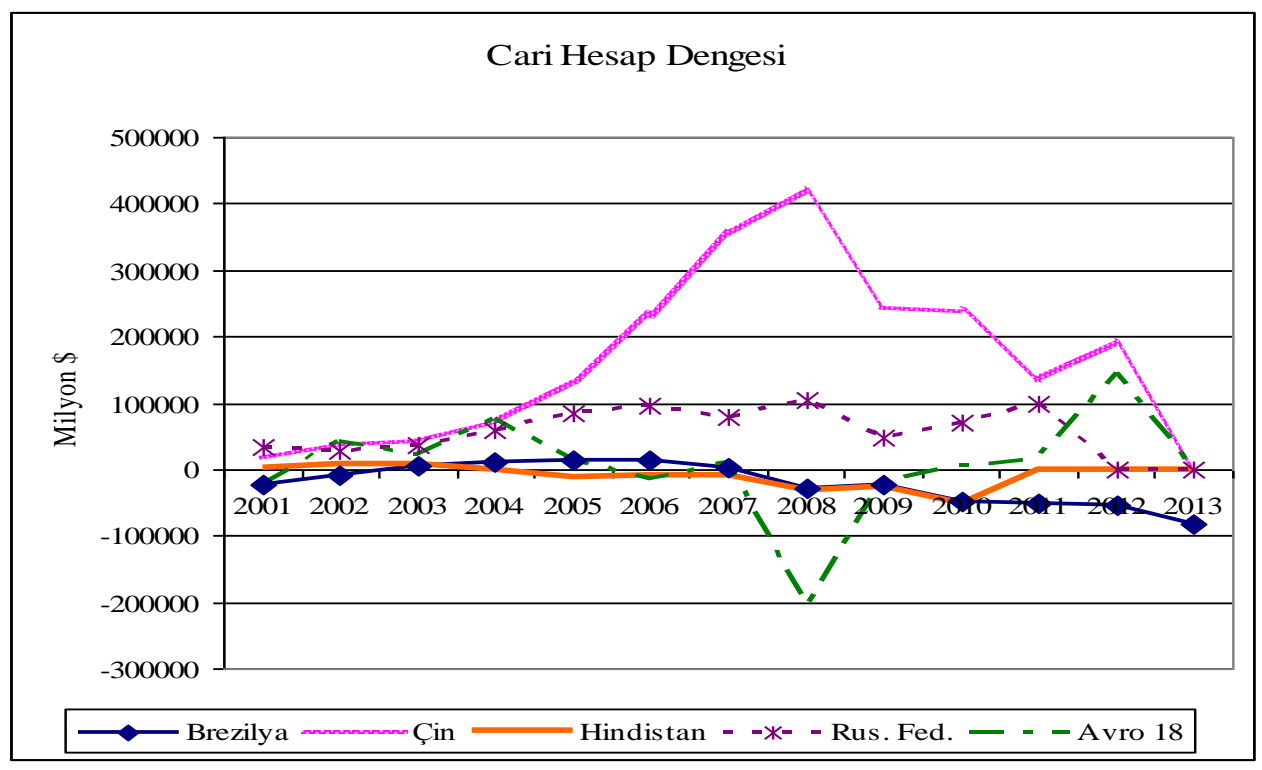

Kaynak: <data.oecd.org〉, 24.02.2014.

\section{Sonuç Yerine}

2007'de ABD'de başlayan ve tüm küreye yayılan kriz, 2008'de okyanus ötesine geçmiş ve Avro Bölgesi'nin birçok ülkesinde ekonomik kriz yaşanmasına sebep olurken Avrupa'nın merkez ülkeleri krizi daha mutedil atlatmayı başarmıştır. ABD'de ortaya çıkan 
krizin Avrupa'ya sıçrama kanallarının neler olduğunu tartışırken karşımıza çıkan ilk öge özelleştirilmiş finansal Keynesçilik olgusu olmuştur. Buna göre, neoliberal düzenlemelerin hız kazanıp bütün piyasaların kuralsızlaşma yönünde hareket ettiği dönemde, üretimden kaynaklı olmayan ama hızla yükselen bir borçlanma trendi gözlenmektedir. Önce ABD'de gelişen ve daha sonra Avrupa'yı da etki alanına alan bu düzenleme fazında hane halkları Keynesyen dönemde devlet harcamaları eliyle karşılanan birçok tüketimlerini ve tasarruflarını özel finans kuruluşları aracılığıyla yapmak durumunda kalmışlardır. Tüm ekonomilere hızla yayılan bu borçlanma virüsü kriz çıkmadan önce bile ekonomileri kırılgan hale getirmiştir. Avrupa'nın ülkelerinde daha da şiddetli yaşanan hane halkı borçlanmasına, Almanya'nın başını çektiği merkez ülkelerin neomerkantil politikaları da eklenince durumları daha da içinden çıkılmaz bir duruma gelmiştir.

Üretkenlik farkları, enflasyon farkları ve teknolojik altyapı farkları bulunmasına rağmen, tek para birime hapsolmuş ülkeler, parasal birliğe girdikleri andan itibaren rekabet güçlerini kaybetmişler ve ihracata dayalı büyüme modelleri çökmüştür. Ülkeler çöküntüden çıkmanın yegane yolu olarak dahili devalüasyon uygulamalarına girişmişler ve fakat kendi yerel dinamiklerinin farklı oluşu ve kısa vadede emek baskılamayla ortaya çıkabilecek avantajların sermaye kesimi tarafından emilmesiyle, ortaya çıkan maliyet düşüşlerini ihracat artışları olarak gerçekleştirememişlerdir.

Sonuç olarak, parasal birliğe bağlı ama ortak bir maliyeden yoksun ülkeler için krizin gelmesi sürpriz olmamıştır ancak krize ortodoks literatürün iddia ettiğinin aksine sadece kendi yerel yetersizlikleri nedeniyle sürüklenmemişlerdir. ABD'de böyle bir kriz yaşanmamış olsaydı da orta ve uzun vadede Avrupa'nın ikili yapısı, doğası gereği ülkeleri krize maruz bırakacaktı. Ancak, dünya kapitalizminin merkezinden yayılan borçlanma ve beraberinde kamunun ekonomiden el çektirilmesi politikaları, neomerkantilist bir savaşta araçsız kalmış IMF’nin acı reçetelerle ‘tedavi’ edilmek istenmesini sadece hızlandırdı.

\section{Kaynakça}

Arestis, P. \& E. Karakitsos (2012), “The US Dimension of the Euro Zone Debt Crisis”, Journal Post Keynesian Economics, 35(1), 21-44.

Arestis, P. \& T. Pelagidis (2010), “Absurd Austerity Policies in Europe", Challenge, 53(6), 54-61.

Arestis, P. \& M. Sawyer (2006), "The Nature and Role of Monetary Policy When Money is Endogenous", Cambridge Journal of Economics, 30(6), 847-860.

Armingeon, K. \& L. Baccaro (2012), "Political Economy of the Sovereign Debt Crisis: The Limits of Internal Devaluation", Industrial Law Journal, 41(3), 254-275.

Bellofiore, R. (2013), “ ‘Two or Three Things I Know About Her': Europe in the Global Crisis and Heterodox Economics", Cambridge Journal of Economics, bet002.

Bellofiore, R. \& F. Garibaldo \& J. Halevi (2010), The Great Recession and the contradictions of European neomercantilism, Bergamo: University of Bergamo.

Crouch, C. (2009), "Privatised Keynesianism: An Unacknowledged Policy Regime", The British Journal of Politics \& International Relations, 11(3), 382-399. 
Edison, H.J. \& E.O.N. Fischer (1991), “A Long-Run View of the European Monetary System”, Journal of International Money and Finance, 10(1), 53-70.

Kitromilides, Y. (2011), "Deficit Reduction, the Age of Austerity, and the Paradox of Insolvency", Journal of Post Keynesian Economics, 33(3), 517-536.

Kuruç, B. (2011), Mustafa Kemal Döneminde Ekonomi: Büyük Devletler ve Türkiye, İstanbul Bilgi Üniversitesi Yayınları.

Lapavitsas, C. \& A. Kaltenbrunner \& G. Lambrinidis \& D. Lindo \& J. Meadway \& J. Michell \& N. Teles (2010), "The Eurozone between Austerity and Default", RMF Discussion Report.

Lucarelli, B. (2011), "German Neomercantilism and the European Sovereign Debt Crisis", Journal of Post Keynesian Economics, 34(2), 205-224.

Mazier, J. \& P. Petit (2013), "In Search of Sustainable Paths for the Eurozone in the Troubled Post2008 World", Cambridge Journal of Economics, 37(3), 513-532.

Markantonatou, M. (2012), "The State and Modes of Regulation in Greece from the Post-War Period to the 2009 Financial Crisis", Journal of Balkan and Near Eastern Studies, 14(4), 416432.

Moore, B.J. (1988), “The Endogenous Money Supply”, Journal of Post Keynesian Economics, 372385 .

Palley, T.I. (1991), “The Endogenous Money Supply: Consensus and Disagreement”, Journal of Post Keynesian Economics, 397-403.

Pérez-Caldentey, E. \& M. Vernengo (2012), “The Euro Imbalances and Financial Deregulation: A Post-Keynesian Interpretation of the European Debt Crisis (No. 702)", Working Paper, Levy Economics Institute.

Weisbrot, M. \& R. Ray (2010), Latvia's Recession: The Cost of Adjustment With An "Internal Devaluation", Centre for Economic and Policy Research. 